\title{
Nitrogen fertiliser value of digested dairy cow slurry, its liquid and solid fractions, and of dairy cow slurry
}

\author{
Daniele Cavalli,, ${ }^{1}$ Giovanni Cabassi, ${ }^{2}$ Lamberto Borrelli, ${ }^{2}$ Roberto Fuccella, ${ }^{2}$ Luigi Degano, ${ }^{2}$ \\ Luca Bechini, ${ }^{1}$ Pietro Marino' \\ ${ }^{1}$ Dipartimento di Scienze Agrarie e Ambientali - Produzione, Territorio, Agroenergia, Università \\ degli Studi di Milano; ${ }^{2}$ Consiglio per la Ricerca e la sperimentazione in Agricoltura - Centro di \\ ricerca per le produzioni foraggere e lattiero-casearie (CRA-FLC), Lodi, Italy
}

\begin{abstract}
An understanding of crop availability of livestock slurry nitrogen (N) is necessary to maximise crop $\mathrm{N}$ use efficiency and to minimise environmental losses. Results from field and laboratory incubation experiments suggest that first-year crop availability of slurry $\mathrm{N}$ comes mainly from its ammonium fraction because net mineralisation of organic $\mathrm{N}$ is often negligible in the short term. A two-year field experiment during 2011 and 2012 in northern Italy was undertaken with several aims: to estimate the $\mathrm{N}$ fertiliser value of raw dairy cow slurry, digested dairy cow slurry, and the liquid and solid fractions of the digested slurry, and to verify if applied ammonium recovery was similar both among slurries and between slurries and inorganic $\mathrm{N}$ fertiliser (ammonium sulphate).
\end{abstract}

Correspondence: Daniele Cavalli, Dipartimento di Scienze Agrarie e Ambientali - Produzione, Territorio, Agroenergia, Università degli Studi di Milano, Italy.

Tel.: +39.02 .50316586 - Fax: +39.02 .50316575 .

E-mail: daniele.cavalli@unimi.it

Key words: apparent nitrogen recovery, crop yield, crop nitrogen uptake, livestock slurries, mineral fertiliser equivalent, maize.

Funding: work carried out within the SINBION project (Sviluppo di sistemi integrati sostenibili per il recupero dei sottoprodotti dell'agro-industria e dell'azienda agraria al fine di ottimizzare la produzione di biogas e valorizzare l'utilizzazione agronomica del digestato; Integrated systems for biogas and nitrogen), funded by the Italian Ministry of Agriculture D.M $\mathrm{n}^{\circ}$ 27335/7303/10 (2 December 2012).

Acknowledgments: we gratefully acknowledge the contribution of Prof. Tommaso Maggiore, Prof. Efisio Piano and Prof. Pierluigi Navarotto in the conception and development of the SINBION project.

Received for publication: 31 December 2013.

Revision received: 5 March 2014.

Accepted for publication: 5 March 2014.

(C) Copyright D. Cavalli et al., 2014

Licensee PAGEPress, Italy

Italian Journal of Agronomy 2014; 9:567

doi:10.4081/ija.2014.567

This article is distributed under the terms of the Creative Commons Attribution Noncommercial License (by-nc 3.0) which permits any noncommercial use, distribution, and reproduction in any medium, provided the original author(s) and source are credited.
Different fertilisers were applied before silage maize cultivation followed by an unfertilised Italian ryegrass crop. The results showed that ammonium recovery was significantly higher in mineral-fertilised (75\%) versus slurry-fertilised (30\%) treatments, except in digested slurry (65\%). This indicates that ammonium applied with organic materials is less efficient than when applied with mineral fertiliser. For the digested slurry and its liquid fraction, most of the applied ammonium was available to the maize during its application year (55\%) due to a low carbon (C)/organic $\mathrm{N}$ ratio. The apparent $\mathrm{N}$ recovery of the raw slurry and digested slurry solid fraction increased substantially between the first $(-1.4 \%)$ and second (20\%) years, as these materials had high C/organic $\mathrm{N}$ ratios; they likely immobilised $\mathrm{N}$ for several months post application, producing residual effects during the Italian ryegrass and next maize crops.

\section{Introduction}

Raw and anaerobically digested livestock slurries can be valuable fertilisers because they supply nutrients and organic matter to the soil.

Anaerobic digestion of organic biomasses has seen considerable growth in Europe (Eurobserv'er, 2013) and in northern Italy (Fabbri et al., 2013) over the last decade.

Many biogas plants co-digest livestock and biomasses to increase methane production, and in northern Italy, energy crops are often dedicated for co-digestion (Fabbri et al., 2013). To facilitate the use of digested slurries as fertilisers, liquid and solid fractions are separated to ease their transport (Möller and Müller, 2012).

A deep understanding of applied slurry nitrogen (N) turnover in soil, and identification of practices to reduce $\mathrm{N}$ losses are required to maximise crop $\mathrm{N}$ use efficiency and to minimise environmental losses. Nutrient management plans (NMPs) maximise crop N use efficiency through calculation of the slurry amount needed for optimal crop production, and determination of application dates that match crop nutrient requirements according to soil type, local climate, and crop characteristics (Grignani et al., 2003). The slurry $\mathrm{N}$ fertiliser value is normally accounted for in a NMP by apparent nitrogen recovery (ANR), an expression of the fraction of applied total $\mathrm{N}$ that on average can be taken up by the crop in a single season after the fertiliser is applied (Schröder, 2005). The ANR depends on local conditions that affect soil water balance, crop growth, and $\mathrm{N}$ turnover. Another expression of $\mathrm{N}$ availability is the mineral fertiliser equivalent (MFE) - also known as the nitrogen fertiliser replacement value (Schröder, 2005) - equals the organic material ANR divided by the inorganic fertiliser ANR. The MFE is considered a more general measure of validity than the ANR because it allows organic material fertiliser values to be compared across pedo-climates.

Raw and digested slurries contain $\mathrm{N}$ in ammonium and organic 
forms. While ammonium $\mathrm{N}\left(\mathrm{NH}_{4}-\mathrm{N}\right)$ is quickly available for crops, organic $\mathrm{N}$ must be mineralised before plants can absorb it. Digested slurries typically have higher $\mathrm{NH}_{4}-\mathrm{N} /$ total $\mathrm{N}$ ratios $(57 \pm 9 \%$, Scrosati, 2010; 44-81\%, Möller and Müller, 2012) than do undigested raw slurries (41 $\pm 10 \%$, De Ferrari et al., 2007; 40-60\%, Gutser et al., 2005), which raises the potential for more $\mathrm{N}$ availability for crops from digested rather than undigested slurries. The literature suggests that first-year $\mathrm{N}$ availability after slurry application to soil is mainly from slurry $\mathrm{NH}_{4}-\mathrm{N}$ content, as opposed to the small contribution that comes from slurry organic $\mathrm{N}$ mineralisation. This hypothesis is supported by field experiments that have related short-term MFE to slurry $\mathrm{NH}_{4}-\mathrm{N}$ content (Möller and Müller, 2012 and references therein; Webb et al., 2013). Moreover, laboratory incubations of livestock slurries have shown that several months after the addition of slurry to the soil, the organic $\mathrm{N}$ net mineralisation is negligible or even negative in the majority of cases (Van Kessel and Reeves, 2002; Morvan et al., 2006; Bechini and Marino, 2009), and that most plant available $\mathrm{N}$ derives from slurry inorganic $\mathrm{N}$. The effects of slurry organic $\mathrm{N}$ on ANR become visible only after slurry is repeatedly applied to the soil, which is when the fertiliser value increases due to slow mineralisation of previously-applied organic N (Gutser et al., 2005; Schröder et al., 2005). Given these findings, we hypothesise that in the short term (13 years, or before residual effects of organic $\mathrm{N}$ become consistent), the MFE of slurry is approximately equal to its $\mathrm{NH}_{4}-\mathrm{N} /$ total $\mathrm{N}$ ratio. If our hypothesis proves true, then the first-year ANR of slurry can be calculated by multiplying its $\mathrm{NH}_{4}$-N/total $\mathrm{N}$ ratio and the ANR of the inorganic fertiliser, specific to site and application time. While this hypothesis appears reasonable for raw slurries (Sørensen et al., 2003; Schröder et al., 2005; Reijs et al., 2007; Schröder et al., 2013), studies of digested slurries and their fractions (Schröder et al., 2007; Chantigny et al., 2008; de Boer, 2008; Möller et al., 2008; Saunders et al., 2012; Sieling et al., 2013) are still rather scarce and insufficient to confirm it. Therefore, the two-year field experiment described in this paper, named SINBION-Field, included three objectives: i) to measure the ANR and MFE of raw, digested, and separated dairy cow slurries; ii) to verify the hypothesis that recovery of applied ammonium is similar among different slurries in the short term; iii) to verify the hypothesis that the recovery of applied ammonium is similar for slurries and inorganic $\mathrm{N}$ fertiliser (ammonium sulphate).

\section{Materials and methods}

\section{Material collection and analysis}

The digested dairy cow slurry and its fractions were obtained from a biogas plant where dairy cow slurry was co-digested with silage maize (about $30 \%$ on a fresh matter basis) and beet pulp (about 1\% on a fresh matter basis). The digested slurry was collected at the outlet of the digester while the liquid and the solid fractions where obtained from the digested slurry after mechanical separation by screw press. The liquid fraction was collected from a storage tank and the solid fraction from a storage heap. The raw dairy cow slurry was sampled from a farm where the storage tank lay beneath the gridded stable floor and litter was not used.

Before analysis, the slurries were homogenised using an Ultra Turrax T-25 disperser (IKA Werke GmbH \& Co. KG, Staufen im Breisgau, Germany) while the solid fraction was hand-chopped. Dry matter (DM) was determined by oven drying at $80^{\circ} \mathrm{C}$ according to Sørensen (1998b). Total N was determined according to the Kjeldahl method, using a Büchi 426 digestion unit and a Büchi 315 distillation unit (BÜCHI Labortechnik AG, Flawil, Switzerland). Concentration of $\mathrm{NH}_{4}-\mathrm{N}$ was determined by steam distillation of the fresh slurry in the presence of excessive MgO and subsequent titration (Clesceri et al., 1998). Total C was determined from oven-dried samples by the dry combustion method using a ThermoQuest NA1500 elemental analyser (Carlo Erba, Milano, Italy). The main characteristics of the materials used in the experiment are reported in Table 1.

\section{Experimental site and design}

The two-year field experiment started during 2011 on a field locat-

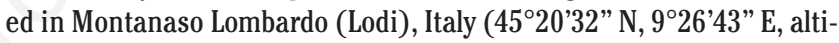
tude $80 \mathrm{~m}$ asl). The field had been cultivated with barley (Hordeum vulgare L.) and maize (Zea mays $\mathrm{L}$.) until the experiment started and had received no organic fertilisers in the previous ten years. The 0-30 cm soil layer had the following characteristics: sand $47 \%$, silt $39 \%$, clay $14 \%, \mathrm{pH}\left(\mathrm{H}_{2} \mathrm{O}\right) 5.8$, total $\mathrm{N}$ and organic carbon (C) (\% DM) 0.10 and 0.84 , extractable phosphorus (P) (Bray and Kurtz method) $61 \mathrm{mg}$ $\mathrm{kg}^{-1}$, exchangeable potassium (K) $167 \mathrm{mg} \mathrm{kg}^{-1}$, and bulk density 1.49 $\mathrm{g} \mathrm{cm}^{-3}$. The climate of the area was characterised by an annual rainfall of about $800 \mathrm{~mm}$ and an average annual mean air temperature of
A

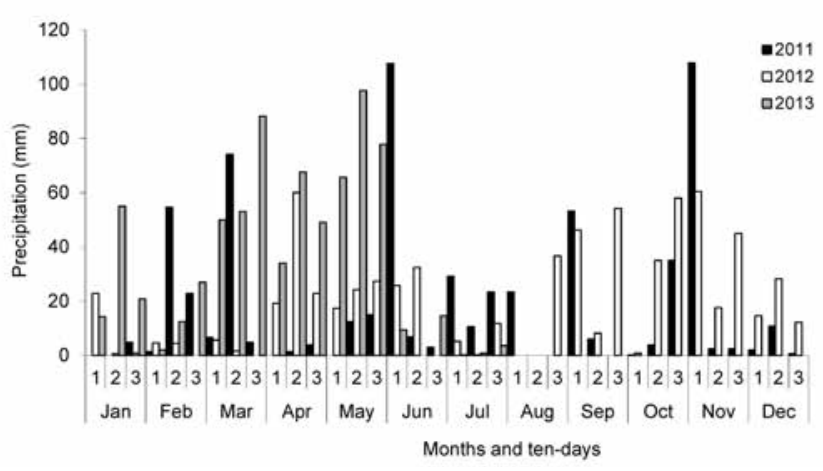

B

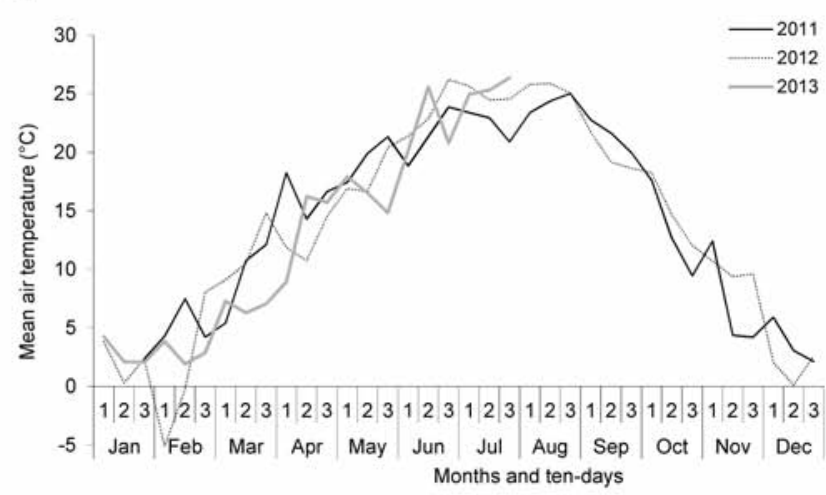

Figure 1. Precipitation (A) and ten-days period mean air temperature (B) collected near the experimental field. 
$12.5^{\circ} \mathrm{C}$, which are reported in Figure 1 for the years 2011-2013.

During spring 2011, six different treatments were established in plots of $112 \mathrm{~m}^{2}$ (length of $15 \mathrm{~m}$; width of $7.5 \mathrm{~m}$ ) each: i) control without $\mathrm{N}$ fertilisation; ii) ammonium sulphate; iii) anaerobically-digested dairy cow slurry; iv-v) the respective liquid and solid fractions of digested slurry following mechanical separation; vi) anaerobically-stored dairy cow slurry. All treatments were replicated four times and arranged in a randomised block experimental design. Ten-meter wide cultivated strips separated adjacent blocks.

A week before spreading, a preliminary sampling of the organic materials was done to calculate the application rate. In order that ammonium recoveries across all the organic treatments could be compared later, the application rate was set so as to deliver the same amount of $\mathrm{NH}_{4}-\mathrm{N}$ to all fertilised treatments. Furthermore, the amount of $\mathrm{NH}_{4}-\mathrm{N}$ distributed was equal to that supplied by the material with the lowest $\mathrm{NH}_{4}-\mathrm{N} /$ total $\mathrm{N}$ ratio (except the solid fraction) applied at $340 \mathrm{~kg}$ $\mathrm{N} \mathrm{ha}^{-1}$. The control and ammonium sulphate treatment plots were also fertilised with P (40 $\left.\mathrm{kg} \mathrm{ha}^{-1}\right)$ and $\mathrm{K}\left(230 \mathrm{~kg} \mathrm{ha}^{-1}\right)$.

On the $31^{\text {st }}$ of May 2011, liquid slurries were applied to the respective plots using a trailing hose spreader and immediately incorporated into the soil with a rotary harrow while on the $17^{\text {th }}$ of May 2012, the liquid slurries were applied by injection to a depth of $15 \mathrm{~cm}$, as the trailing hose spreader was unavailable. On the same days reported above, chemical fertilisers and the solid fraction were hand spread and immediately incorporated into the soil with a rotary harrow.

In both years, after all fertiliser applications, the field was ploughed, and within three days, maize was sown (Hybrid PR33M15; Pioneer HiBred Italia S.r.l., Gadesco-pieve Delmona Cremona, Italy). During the maize growing season, the field was surface-irrigated four times, depending on turns and precipitations.

In summer 2012 and 2013, after the maize harvest, the field was sown with Italian ryegrass (Lolium multiflorum Lam., cultivar Asso) with no additional fertilisations.

\section{Crop harvest and analysis}

Maize was harvested at milky-waxy maturity (R5; Ritchie et al., 1996) on 13 September 2011 and on 30 August 2012. The Italian ryegrass was harvested on 10 May 2012 and on 13 May 2013.

The above ground biomass (AGB) of maize was estimated from 40 hand-harvested plants per plot; plants were collected from the eight inner rows of each plot. Italian ryegrass AGB was estimated from the inner $22 \mathrm{~m}^{2}$ of each plot. A sub-sample (about $3 \mathrm{~kg}$ ) of harvested maize and ryegrass was oven dried $\left(105^{\circ} \mathrm{C}\right)$ and ground with a rotary-knife mill equipped with a sieve of $4 \mathrm{~mm}$ mesh; thereafter, an aliquot (about $150 \mathrm{~g}$ ) was ground with a ZM 100 centrifugal mill equipped with a sieve of $0.5 \mathrm{~mm}$ mesh (Retsch Gmbh \& Co., Haan, Germany). Total N was determined by dry combustion using a ThermoQuest NA1500 elemental analyser (Carlo Erba).

\section{Soil sampling and analysis}

Soil samples (0-30 cm layer) were collected from each plot before fertilisation (in the year 2011) and immediately after crop harvest. Prior to fertilisation and after ryegrass harvest, six random sub-samples were taken from each plot and combined to give one representative sample. Similarly, after maize harvest, one representative sample was derived from each plot by combining six random sub-samples taken from three different plot locations: two along maize rows, two between rows, and two about $20 \mathrm{~cm}$ away from rows. This sampling technique was adopted to account for the non-uniform location of applied liquid slurries in the plot. Soil samples were analysed according to Italian official methods for physical and chemical analyses of soil (MiPAAF, 1997, 2000). Specifically, soluble and exchangeable $\mathrm{NH}_{4}{ }^{+}$and $\mathrm{NO}_{3}{ }^{-}$were extracted for two hours using a solution of $1 \mathrm{M} \mathrm{KCl}$ (extraction ratio 1:3). Suspensions of each derived sample were then prepared by filtration through Whatman \#2 filter paper (Whatman International Ltd., Maidstone, England), followed by storage at $-20^{\circ} \mathrm{C}$ until analysis. Ammonium and nitrate concentrations in the soil extracts were determined by flow injection analysis and spectrometric detection (FIAstar 5000 Analyzer; Foss Tecator, Hillerød Denmark).

\section{Calculations and statistical analysis}

Subtracting maize $\mathrm{N}$ uptake in the control treatment from maize $\mathrm{N}$ uptake in the fertilised treatment and dividing the result by the total $\mathrm{N}$ (ANR) or $\mathrm{NH}_{4}-\mathrm{N}\left(\mathrm{ANR}_{\mathrm{NH} 4-\mathrm{N}}\right)$ applied in separated calculations for years one (2011-2012) and two (2012-2013) results in an ANR value. The MFE of the organic materials was calculated as the ratio

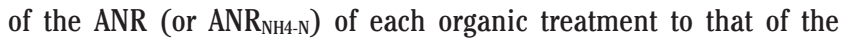
ammonium sulphate treatment. An analysis of variance (ANOVA) was performed separately for each growing season (2011-2012 and 2012-2013) using the SPSS procedure UNIANOVA (SPSS Version 19.0.0). Mean separation was conducted with the Tukey's honest significant difference test $(\mathrm{P}<0.05)$. The treatment and block were considered fixed factors. Homogeneity of variances was evaluated using the Levene test $(\mathrm{P}<0.05)$.

Table 1. Characteristics of the organic fertilisers applied before maize sowing in 2011 and 2012.

\begin{tabular}{|c|c|c|c|c|c|c|c|c|}
\hline Fertiliser & Year & $\begin{array}{l}\text { DM } \\
(\%)\end{array}$ & $\begin{array}{c}\mathrm{C} \\
(\% \mathrm{DM})\end{array}$ & Total N & $\mathrm{NH}_{4}-\mathrm{N}$ & $\begin{array}{l}\text { C/organic N } \\
\left(\mathrm{g} \mathrm{C} \mathrm{g} \mathrm{N}^{-1}\right)\end{array}$ & $\begin{array}{l}\text { VFA-C } \\
(\% \mathrm{C})\end{array}$ & $\mathrm{pH}\left(\mathrm{H}_{2} \mathrm{O}\right)$ \\
\hline \multirow[t]{2}{*}{ Digested slurry } & 2011 & $6.5^{\circ}$ & $39.58 \pm 0.58$ & $5.59 \pm 0.03$ & $2.55 \pm 0.03$ & 13.0 & $0.15 \pm 0.00$ & $7.96 \pm 0.01$ \\
\hline & 2012 & $6.1^{\circ}$ & $38.94 \pm 0.03$ & $6.13 \pm 0.03$ & $2.86 \pm 0.01$ & 11.9 & $0.44 \pm 0.01$ & $8.22 \pm 0.00$ \\
\hline \multirow[t]{2}{*}{ Liquid fraction } & 2011 & $4.8^{\circ}$ & $36.36 \pm 0.22$ & $6.70 \pm 0.01$ & $3.42 \pm 0.00$ & 11.1 & $0.17 \pm 0.00$ & $8.03 \pm 0.01$ \\
\hline & 2012 & $5.4^{\circ}$ & $38.36 \pm 0.43$ & $6.52 \pm 0.00$ & $3.29 \pm 0.01$ & 11.9 & $2.47 \pm 0.07$ & $7.91 \pm 0.01$ \\
\hline \multirow[t]{2}{*}{ Solid fraction } & 2011 & $25.7^{\circ}$ & $43.98 \pm 0.55$ & $2.19 \pm 0.02$ & $0.51 \pm 0.00$ & 26.3 & $0.00^{\circ}$ & $9.62 \pm 0.01$ \\
\hline & 2012 & $29.6^{\circ}$ & $43.67 \pm 0.45$ & $2.09 \pm 0.04$ & $0.78 \pm 0.03$ & 33.3 & $0.51^{\circ}$ & $8.97 \pm 0.25$ \\
\hline \multirow[t]{2}{*}{ Stored slurry } & 2011 & $8.2^{\circ}$ & $43.64 \pm 0.13$ & $3.92 \pm 0.02$ & $2.08 \pm 0.02$ & 23.7 & $7.92 \pm 0.04$ & $7.30 \pm 0.01$ \\
\hline & 2012 & $8.4^{\circ}$ & $42.77 \pm 0.58$ & $4.31 \pm 0.03$ & $2.17 \pm 0.01$ & 20.0 & $7.42 \pm 0.02$ & $7.32 \pm 0.00$ \\
\hline
\end{tabular}

DM, dry matter; C, carbon; $\mathrm{N}$, nitrogen; $\mathrm{NH}_{4}-\mathrm{N}$, ammonium $\mathrm{N} ; \mathrm{VFA}$, volatile fatty acids. ${ }^{\circ}$ Single determination. 


\section{Results}

\section{Applied $\mathrm{NH}_{4}-\mathrm{N}$}

The amount of $\mathrm{NH}_{4}-\mathrm{N}$ calculated to be applied to all fertilised treatments was $159 \mathrm{~kg} \mathrm{NH}_{4}-\mathrm{N} \mathrm{ha}^{-1}$ in 2011 and $152 \mathrm{~kg} \mathrm{NH}_{4}-\mathrm{N} \mathrm{ha}^{-1}$ in 2012, which was equivalent to the amount effectively applied in the ammonium sulphate treatment (Table 2). However, the rate of $\mathrm{NH}_{4}-\mathrm{N}$ applied (Table 2) might have differed in the organic treatments for two reasons: i) estimated $\mathrm{N}$ concentrations of the organic materials at the preliminary sampling and at the time of spreading showed some differences; and ii) during 2011 difficulties with slurry spreader calibration led to deviations from calculated application rates. We assumed that trailing hose followed by rotary harrow (2011) produced levels of ammonia emissions similar to those of direct injection (2012).

\section{Above ground biomass}

In 2011, maize AGB (Figure 2A) ranged between 16.5 and 22.3 t DM $\mathrm{ha}^{-1}$ and was similar in all treatments. In 2012, the application of fertilisers increased maize AGB by 6.8-11.8 $\mathrm{t} \mathrm{DM} \mathrm{ha}^{-1}$ compared to the control (12.3 $\left.\mathrm{t} \mathrm{DM} \mathrm{ha}^{-1}\right)$. In year one of the experiment, Italian ryegrass AGB (Figure 2B), on average, was 1.6 t DM ha-1 higher in the fertilised treatments relative to the control $\left(5.6 \mathrm{tDM} \mathrm{ha}^{-1}\right)$, with the exception of the solid fraction where it reached 8.6 t DM ha ${ }^{-1}$. In 2013, solid fraction application resulted in significant $(\mathrm{P}<0.05)$ increases in Italian ryegrass AGB (1.0-2.3 t DM hal $)$ compared to the other treatments.

\section{Apparent nitrogen recovery}

In the first year of the experiment, the apparent nitrogen recovery (ANR) of maize was significantly higher $(\mathrm{P}<0.05)$ (38 to 72 percentage points) in the ammonium sulphate treatment compared to the organic treatments (Figure 3A). In the same year, ANR was significantly higher $(\mathrm{P}<0.05)$ in the digested slurry and liquid fraction treatments $(29.6$ and $19.9 \%$, respectively) with respected to the stored slurry treatment $(-3.8 \%)$. In 2012, ammonium sulphate significantly increased $(\mathrm{P}<0.05)$ ANR in maize, from 52 to 60 percentage points, compared to the other treatments. Among the organic materials, no significant differences were found (Figure 3A).

Application of ammonium sulphate significantly increased $(\mathrm{P}<0.05)$ the $\mathrm{ANR}_{\mathrm{NH} 4 \mathrm{~N}}$ in maize by 69 (2011) and by 37 (2012) percentage points compared to the solid fraction and stored slurry (Figure 3B) treatments. Furthermore, in 2011, ANR $_{\mathrm{NH4}-\mathrm{N}}$ was significantly higher $(\mathrm{P}<0.05)$ in the digested slurry $(64.9 \%)$ relative to the solid fraction and the stored slurry (4.8 and $-7.2 \%$, respectively). As observed for ANR, there were no significant differences of $\mathrm{ANR}_{\mathrm{NH} 4 \mathrm{~N}}$ among the 2012 organic treatments.

Table 2. Amount of total nitrogen (N) and ammonium $\mathrm{N}$ applied before maize sowing in 2011 and $2012\left(\mathrm{~kg} \mathrm{~N} \mathrm{ha}^{-1}\right)$.

\begin{tabular}{|c|c|c|c|c|c|}
\hline Year & Ammonium sulphate & Digested slurry & $\begin{array}{l}\text { Treatment } \\
\text { Liquid fraction }\end{array}$ & Solid fraction & Stored slurry \\
\hline \multicolumn{6}{|c|}{ Total N } \\
\hline 2011 & 159 & 263 & 217 & 645 & 200 \\
\hline 2012 & 152 & 305 & 291 & 606 & 270 \\
\hline $\begin{array}{l}\mathrm{NH}_{4}-\mathrm{N} \\
2011 \\
2012\end{array}$ & $\begin{array}{l}159 \\
152\end{array}$ & $\begin{array}{l}120 \\
142\end{array}$ & $\begin{array}{l}111 \\
147\end{array}$ & $\begin{array}{l}151 \\
226\end{array}$ & $\begin{array}{l}106 \\
136\end{array}$ \\
\hline
\end{tabular}

$\mathrm{N}$, nitrogen; $\mathrm{NH}_{4}-\mathrm{N}$, ammonium $\mathrm{N}$.

A

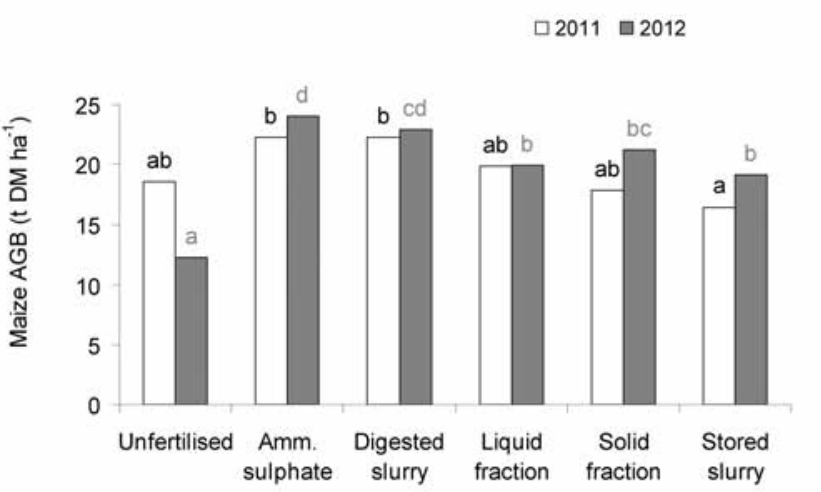

B

$\square 2012 \square 2013$

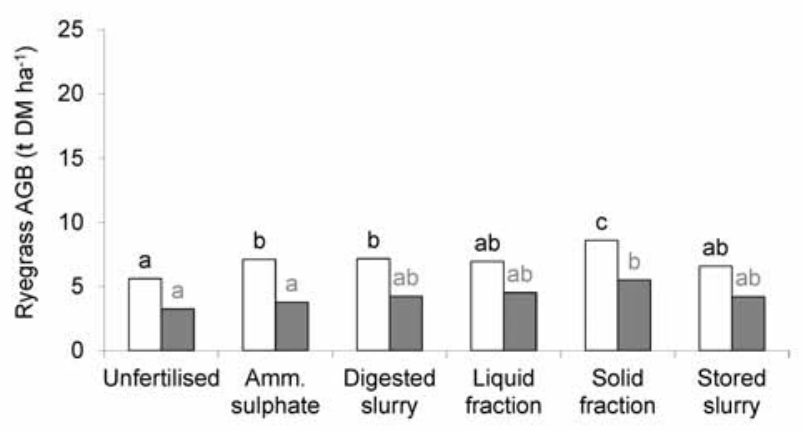

Figure 2. Above ground biomass (AGB) of maize (A) and Italian ryegrass (B) at crop harvest. Within the same chart and the same year, means with different letters are significantly different $(\mathrm{P}<0.05)$ according to the Tukey's honest significant difference test. 


\section{Mineral fertiliser equivalent}

In 2011, MFE (Figure 4A) was significantly higher $(\mathrm{P}<0.05)$ in the digested slurry and liquid fraction ( 43.5 and $29.3 \%$, respectively) compared to the stored slurry $(-5.6 \%)$, and in the digested slurry compared to the solid fraction (1.6\%). In 2012, MFE was significantly higher $(\mathrm{P}<0.05)$ only in the digested slurry $(36.7 \%)$ relative to the solid fraction (21.1\%). In both years, $\mathrm{MFE}_{\mathrm{NH} 4 \mathrm{~N}}$ (Figure $4 \mathrm{~B}$ ) was significantly higher $(\mathrm{P}<0.05)$ in the digested slurry $(95.5$ and $78.9 \%$, respectively) with respect to the solid fraction (7.0 in 2011 and $56.7 \%$ in 2012) and stored slurry treatments (10.6 in 2011 and $53.8 \%$ in 2012).

\section{Soil mineral nitrogen}

In 2011, soil mineral nitrogen at maize harvest (Figure 5A) averaged $6.7 \mathrm{~kg} \mathrm{~N} \mathrm{ha}^{-1}$. In the following season, the measurement averaged 13.0 $\mathrm{kg} \mathrm{N} \mathrm{ha}{ }^{-1}$ in all treatments, except in the solid fraction where it was about twice the average. At the 2011 ryegrass harvest, between 0.8 and $3.7 \mathrm{~kg} \mathrm{~N} \mathrm{ha}^{-1}$ was present in the soil (Figure 5B), as opposed to the 2012 harvest when the mineral nitrogen soil concentration ranged between 5.6 and $9.6 \mathrm{~kg} \mathrm{~N} \mathrm{ha}^{-1}$.
A

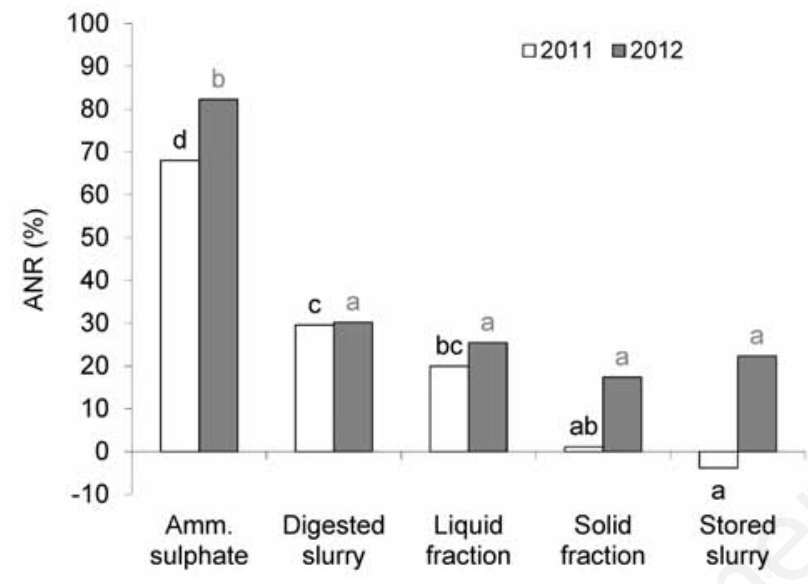

B

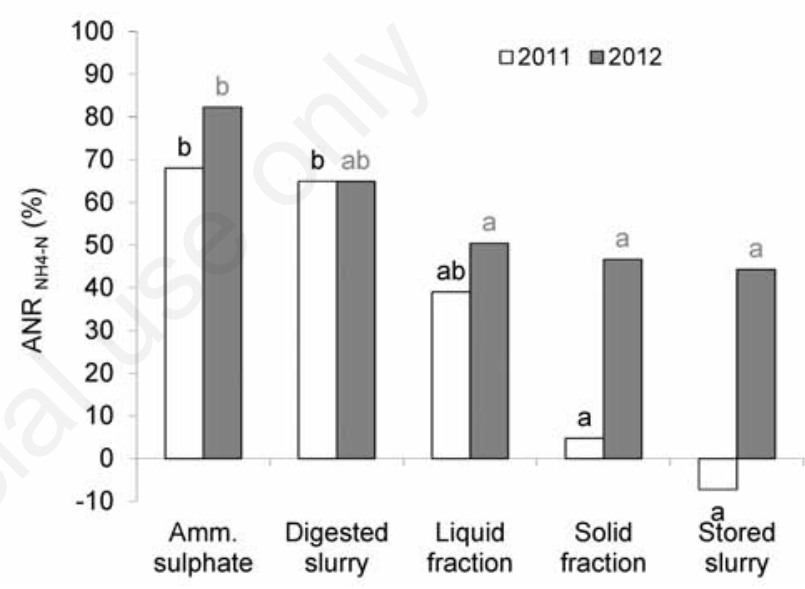

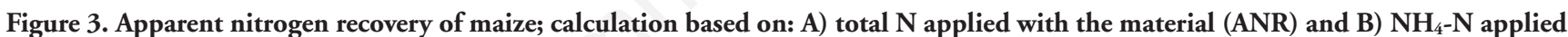
with the material $\left(\mathrm{ANR}_{\mathrm{NH} 4-\mathrm{N}}\right)$. Within the same chart and the same year, means with different letters are significantly different $(\mathbf{P}<0.05)$ according to the Tukey's honest significant difference test.

A

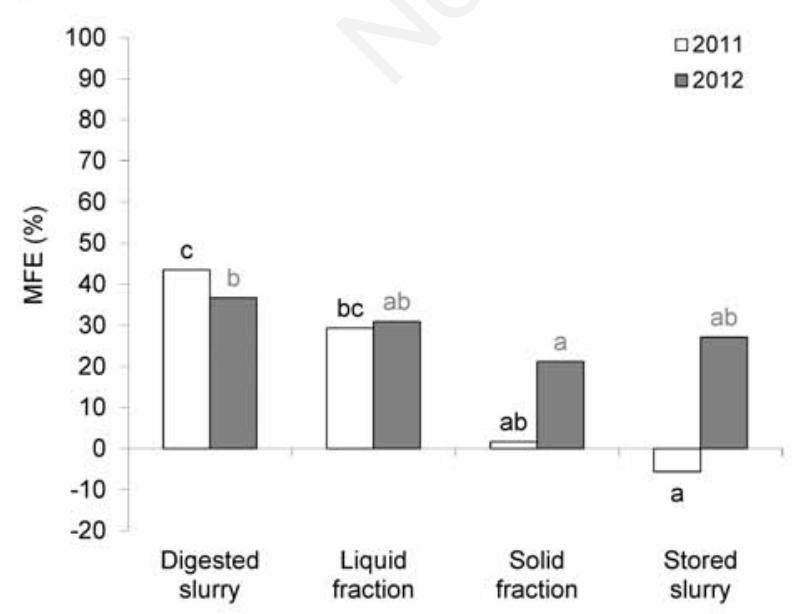

B

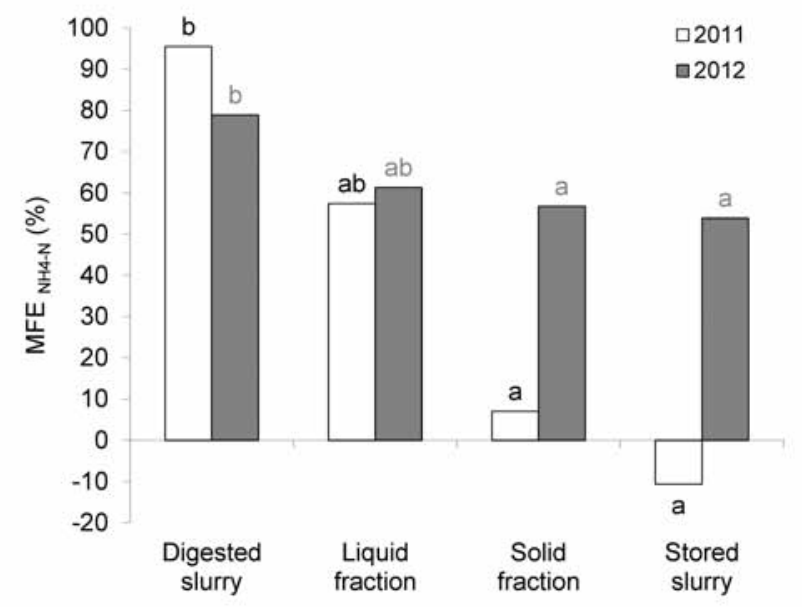

Figure 4. Mineral fertiliser equivalent of maize; calculation based on: $\mathrm{A}$ ) total $\mathrm{N}$ applied with the material (MFE) and B) $\mathrm{NH}_{4}-\mathrm{N}$ applied with the material $\left(\mathrm{MFE}_{\mathrm{NH} 4-\mathrm{N}}\right)$. Within the same chart and the same year, means with different letters are significantly different $(\mathrm{P}<0.05)$ according to the Tukey's honest significant difference test. 
A

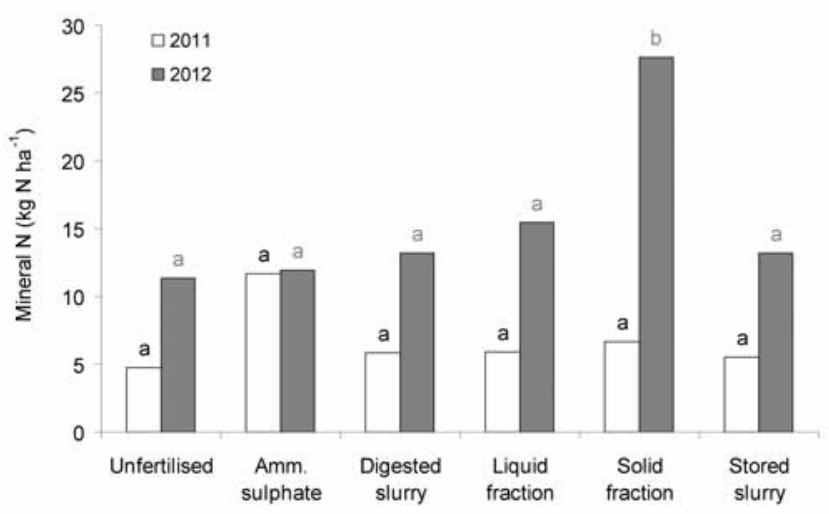

B

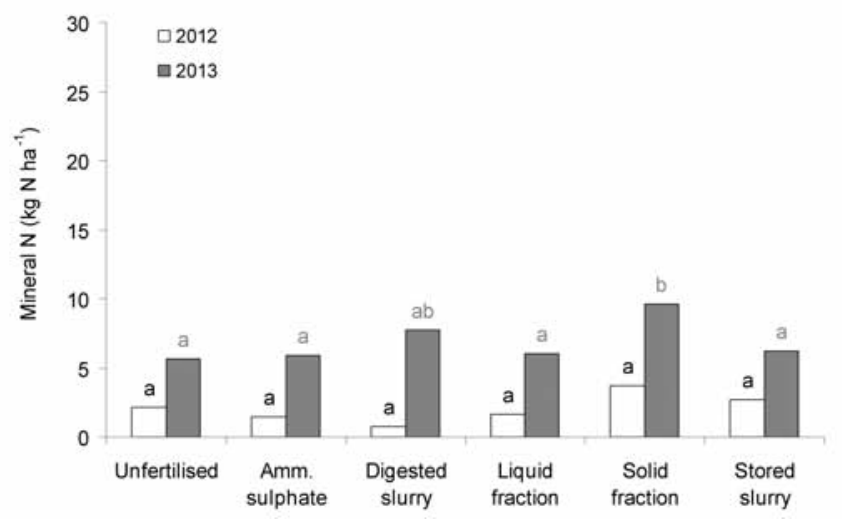

Figure 5. Soil mineral nitrogen concentration at maize $(A)$ and Italian ryegrass $(B)$ harvest. Within the same chart and the same year, means with different letters are significantly different $(P<0.05)$ according to the Tukey's honest significant difference test.

\section{Discussion}

In both years, the ammonium sulphate treatment $\mathrm{ANR}_{\mathrm{NH} 4-\mathrm{N}}$ was higher than in the organic treatments, with the exception of digested slurry. Indeed, all the materials were immediately incorporated into the soil after spreading in order to reduce volatilisation of $\mathrm{NH}_{3}$ (Sommer and Hutchings, 2001); hence, the amount of soil mineral N was likely similar in all treatments immediately after fertilisation. Moreover, maize $\mathrm{N}$ recovery in the ammonium sulphate treatment was high in both years (68\% in 2011 and $82 \%$ in 2012) (Figure 3A), suggesting that mineral $\mathrm{N}$ losses were inconsistent during maize growing seasons. Organic matter turnover-related processes in the organic treatments, demonstrated by digested slurry and liquid fraction versus solid fraction and stored slurry, can explain the different $2011 \mathrm{ANR}_{\mathrm{NH} 4 \mathrm{~N}}$ measurements.

Considering organic treatments (Figure 3) solely, 2011 ANR and $\mathrm{ANR}_{\mathrm{NH} 4 \mathrm{~N}}$ values for digested slurry were higher than for either solid fraction or stored slurry. These differences in ANR and $\mathrm{ANR}_{\mathrm{NH} 4 \mathrm{~N}}$ values among the slurries in 2011 are likely due to differences in the availability of applied mineral $\mathrm{N}$ for the crop.

In the first experimental year, higher $\mathrm{NH}_{4}-\mathrm{N}$ recovery in digested slurry compared to solid fraction and stored slurry (Figure $3 \mathrm{~B}$ ) might derive from organic matter chemical composition and decomposition dynamic differences among the three materials that led to differences in mineral $\mathrm{N}$ crop availability. The organic matter of digested slurry presumably composed of rather stable organic matter after anaerobic digestion (Möller and Müller, 2012) - had a low C/organic N ratio (Table 1). Decomposition in the soil of the digested slurry probably induced a short and low net $\mathrm{N}$ immobilisation, which made the applied $\mathrm{NH}_{4}-\mathrm{N}$ fully available for maize following slurry application. Further support of this likelihood is its ammonium sulphate treatment-like $\mathrm{ANRNH}_{4}-\mathrm{N}$ value.

Similar first-year $\mathrm{ANR}_{\mathrm{NH} 4 \mathrm{~N}}$ values for digested cattle slurry and mineral fertiliser were also found in a three-year field experiment by Schröder et al. (2007) in which anaerobically-digested cattle slurry was applied to cut grassland; the authors reported $\mathrm{ANRNH}_{4-\mathrm{N}}$ values of $64-$ $69 \%$ and $63-70 \%$ for digested cattle slurry and mineral fertiliser, respectively.

Alternatively, an important fraction of mineral $\mathrm{N}$ applied with solid fraction and stored slurry might have been immobilised by soil microflora during decomposition. Indeed, these materials had high C/organic $\mathrm{N}$ ratios (Table 1), and presumably, less stable organic matter - two conditions that promote microbial immobilisation of $\mathrm{N}$ following soil incorporation (Chadwick et al., 2000; Peters and Jensen, 2011). In fact, the solid fraction contained the least-decomposed part of the digested slurry (i.e., the fibrous fraction), while the stored slurry was rich in volatile fatty acids (VFA) (Table 1). Incubation experiments have shown that both fibrous fraction (Van Kessel et al., 2000; Morvan and Nicolardot, 2009; Peters and Jensen, 2011) and VFA (Kirchmann and Lundvall, 1993; Sørensen, 1998a) induce net immobilisation of mineral $\mathrm{N}$ during their decomposition in the soil.

The ammonium recoveries obtained in our experiment for raw cattle slurry are different from those obtained by others. Sørensen (2004) conducted a field experiment that reported a first-year $\mathrm{NH}_{4}-\mathrm{N}$ recovery of $72 \%$ (injected cattle slurry) and $76 \%$ (mineral fertiliser) applied to barley with undersown ryegrass. Schröder et al. (2007) reported $\mathrm{ANR}_{\mathrm{NH4-N}}$ values for two injected cattle slurries applied to cut grassland in the range of $62-76 \%$, which is comparable to the $63-70 \%$ for the mineral fertiliser (calcium ammonium nitrate) obtained in the same trial. Another field experiment by Schröder et al. (2013) resulted in higher ammonium ANRs compared to our experiment; they reported a firstyear $\mathrm{ANR}_{\mathrm{NH} 4 \mathrm{~N}}$ of $58 \%$ for both injected cattle slurry and mineral fertiliser applied to silage maize. The high ammonium recoveries obtained by Schröder et al. $(2007,2013)$ can be ascribed to the relatively lower range (15-16) of $\mathrm{C}$ to organic $\mathrm{N}$ ratio for the cattle slurry used in those field experiments - and thus to a lower $\mathrm{N}$ immobilisation - as compared to those of raw slurry used in our trial (20-24).

The values of $\mathrm{ANR}_{\mathrm{NH} 4 \mathrm{~N}}$ for solid fraction (5-47\%) obtained in our experiment were close to the range (12-63\%) reported for solid cattle manures by Muñoz et al. (2004), indicating a general lower short-term ammonium availability for crops from solid manures compared to liquid slurries. As opposed to 2011, in 2012, ANR and ANR $_{\mathrm{NH} 4-\mathrm{N}}$ were very similar across the organic treatments, with an average recovery of applied total $\mathrm{N}$ and $\mathrm{NH}_{4}-\mathrm{N}$ of $24 \%$ and $52 \%$, respectively. Across-year ANR comparisons showed similar 2011 and 2012 values for digested slurry and liquid fraction, which contrasted with the markedly higher ANR values of 2012 versus 2011 in solid fraction and stored slurry treatments.

The fact that solid fraction and stored slurry had markedly higher ANRs in 2012 compared to 2011 (and higher ANR similarity with all slurries observed in 2012) might arise not only from remineralisation 
of a fraction of 2011 immobilised $\mathrm{N}$, but also from slow mineralisation in 2012 of recalcitrant organic compounds not fully mineralised in the previous year (Sørensen, 2004; Schröder et al., 2005). Such a hypothesis would explain the higher residual effect observed in Italian ryegrass in 2011 with solid fraction compared to the digested slurry and liquid fraction, and with the higher residual effect observed on maize in 2012 in solid fraction and stored slurry treatments compared to digested slurry and liquid fraction (Schröder et al., 2007).

As for MFE and $\mathrm{MFE}_{\mathrm{NH} 4 \mathrm{~N}}$ values of the organic fertilisers (Figure 4), they reflected the same patterns observed for ANR and $\mathrm{ANR}_{\mathrm{NH} 4 \mathrm{~N} \text {. In }}$ 2012, MFE averaged 34\% (digested slurry and liquid fraction), $27 \%$ (stored slurry), and 21\% (solid fraction).

The substantially lower MFE values (Figure 4A) compared with $\mathrm{NH}_{4}$ $\mathrm{N}$ to total $\mathrm{N}$ ratios (Table 1) for solid and liquid fractions and for stored slurry contradicted our hypothesis that slurry ammonium is completely available during the first year after application. In fact, the hypothesis was verified only for digested slurry (in both 2011 and 2012). Furthermore, any $\mathrm{MFE}_{\mathrm{NH} 4-\mathrm{N}}$ values lower than $100 \%$ (Figure $4 \mathrm{~B}$ ) contradicted the hypothesis that slurry ammonium is as available as ammonium applied with inorganic fertiliser.

Two points deserve mention relative to this work. First, the results from this and other experiments (Nevens and Reheul, 2005) have shown that the ANRs of some materials tend to increase over time. Therefore, the ANR published in this article might underestimate the real $\mathrm{N}$ availability of livestock farms where slurries have been spread annually for decades. In these cases, raw slurry ANRs typically ranges between 50-70\% (Nevens and Reheul, 2005; Zavattaro et al., 2012). Second, at least in the short term (when residual effects are not yet clearly visible), it is not sufficient to estimate ANR by simply using the $\mathrm{NH}_{4}-\mathrm{N} /$ total $\mathrm{N}$ ratio. In fact, for materials with high $\mathrm{C} /$ organic $\mathrm{N}$ ratios (solid fraction, and raw slurry to a lesser extent), net $\mathrm{N}$ mineralisation occurs months after their application (Peters and Jensen, 2011). Therefore, in addition to compensating crop $\mathrm{N}$ requirements with inorganic fertilisers, cultivating a catch crop might be considered to absorb mineralised $\mathrm{N}$ during periods outside the growing season of the crop that first received the organic fertilisers.

\section{Conclusions}

The $\mathrm{ANR}_{\mathrm{NH} 4 \mathrm{~N}}$ of digested slurry was rather close to that of ammonium sulphate, indicating that the ammonium in digested slurry could be managed to simulate inorganic fertilisers in terms of application rate and timing. On the other hand, ammonium in the solid fraction of digested slurry and in raw slurry during the first year after application was less available than it was in digested slurry; however, for these two materials, the ANR increased in year two.

These results imply that for cases in which either raw slurry or the solid fraction of digested slurry is occasionally applied, such as it might be in rented fields on non-livestock farms, resulting nitrogen fertilisation values may be lower than those reported in the literature which typically arise from fields that received manure applications for decades. With repeated applications of these materials, the ANR will increase year after year. Further research is needed on long-term solid fraction of digested slurry fertilisation values.

\section{References}

Bechini L, Marino P, 2009. Short-term nitrogen fertilizing value of liq- uid dairy manures is mainly due to ammonium. Soil Sci. Soc. Am. J. 73:2159-69.

Chadwick DR, John F, Pain BF, Chambers BJ, Williams J, 2000. Plant uptake of nitrogen from the organic nitrogen fraction of animal manures: a laboratory experiment. J. Agr. Sci. 134:159-68.

Chantigny MH, Angers DA, Bélanger G, Rochette P, Eriksen-Hamel N, Bittman S, Buckley K, Massé D, Gasser M, 2008. Yield and nutrient export of grain corn fertilized with raw and treated liquid swine manure. Agron. J. 100:1303-9.

Clesceri LS, Greenberg AE, Eaton AD, 1998. Standard methods for the examination of water and wastewater. $20^{\text {th }}$ ed. APHA, AWWA, WPCF, Washington, DC, USA.

de Boer HC, 2008. Co-digestion of animal slurry can increase shortterm nitrogen recovery by crops. J. Environ. Qual. 37:1968-73.

De Ferrari G, Marino Gallina P, Cabassi G, Bechini L, Maggiore T, 2007. Near infrared spectral analysis of cattle slurries from Lombardy (Northern Italy) breeding farms. pp 630-637 in G.R. BurlingClaridge et al. (ed.), NIR 2005-NIR in action. Making a difference. Near infrared spectroscopy. Proc. Int. Conf., Auckland, New Zealand, 9-15 April 2005. New Zealand Near Infrared Spectroscopy Soc. Inc., Hamilton, New Zealand.

Eurobserv'er, 2013. The state of renewable energies in Europe. Edition 2013. 13th Eurobserv'ER Report. Available from: http://www.eurobserv-er.org/

Fabbri C, Labartino N, Manfredi S, Piccinini S, 2013. Biogas, il settore è strutturato e continua a crescere. Inf. Agrario 11:11-8.

Grignani C, Bassanino M, Sacco D, Zavattaro L, 2003. Il bilancio degli elementi nutritivi per la redazione del piano di concimazione. Riv. Agron. 37:155-72.

Gutser R, Ebertseder Th, Weber A, Schraml M, Schmidhalter U, 2005. Short-term and residual availability of nitrogen after long-term application of organic fertilizers on arable land. J Plant. Nutr. Soil Sci. 168:439-46.

Kirchmann H, Lundvall A, 1993. Relationship between N immobilization and volatile fatty acids in soil after application of pig and cattle slurry. Biol. Fertil. Soils 15:161-4.

MiPAAF (Italian Ministry of Agricultural, Food and Forestry Policies), 1997. Analytical methods for physical analysis of soils. Franco Angeli, Milano, Italy.

MiPAAF (Italian Ministry of Agricultural, Food and Forestry Policies), 2000. Analytical methods for chemical analyses of soils. Franco Angeli, Milano, Italy.

Morvan T, Nicolardot B, 2009. Role of organic fractions on C decomposition and $\mathrm{N}$ mineralization of animal waste in soil. Biol. Fertil. Soils 45:477-86.

Morvan T, Nicolardot B, Péan L, 2006. Biochemical composition and kinetics of $\mathrm{C}$ and $\mathrm{N}$ mineralization of animal wastes: a typological approach. Biol. Fertil. Soils 42:513-22.

Möller K, Müller T, 2012. Effects of anaerobic digestion on digestate nutrient availability and crop growth: A review. Eng. Life Sci. 12:242-57.

Möller K, Stinner W, Deuker A, Leithold G, 2008. Effects of different manuring systems with and without biogas digestion on nitrogen cycle and crop yield in mixed organic dairy farming systems. Nutr. Cycl. Agroecosyst. 82:209-32.

Muñoz GR, Kelling KA, Powell JM, Speth PE, 2004. Comparison of estimates of first-year dairy manure nitrogen availability or recovery using nitrogen-15 and other techniques. J. Environ. Qual. 33:719-27.

Nevens F, Reheul D, 2005. Agronomical and environmental evaluation of a long-term experiment with cattle slurry and supplemental inorganic $\mathrm{N}$ applications in silage maize. Eur J. Agron. 22:349-61.

Peters K, Jensen LS, 2011. Biochemical characteristics of solid fractions from animal slurry separation and their effects on $\mathrm{C}$ and $\mathrm{N}$ 
mineralization in soil. Biol. Fertil. Soils 47:447-55.

Reijs JW, Sonneveld MPW, Sørensen P, Schils RLM, Groot JCJ, Lantinga EA, 2007. Effects of different diets on utilization of nitrogen from cattle slurry applied to grassland on a sandy soil in The Netherlands. Agr. Ecosyst. Environ. 118:65-79.

Ritchie SW, Hanway JJ, Benson G0, 1996. How a corn plant develops. Special Report No. 48, Rev. ed. Iowa State University Cooperative Extension Service, Ames, Iowa, USA.

Saunders OE, Fortuna A, Harrison JH, Whitefield E, Cogger CG, Kennedy AC, Bary AI, 2012. Comparison of raw dairy manure slurry and anaerobically digested slurry as $\mathrm{N}$ sources for grass forage production. Int. J. Agron. 2012:1-10.

Scrosati M, 2010. Caratterizzazione dei digestati e loro frazioni al fine di una corretta utilizzazione agronomica. Master degree thesis. University of Milano, Italy.

Schröder JJ, 2005. Revisiting the agronomic benefits of manure: a correct assessment and exploitation of its fertilizer value spares the environment. Bioresour. Technol. 96:253-61.

Schröder JJ, de Visser W, Assinck FBT, Velthof, GL, 2013. Effects of short-term nitrogen supply from livestock manures and cover crops on silage maize production and nitrate leaching. Soil Use Manage. 29:151-60.

Schröder JJ, Jansen AG, Hilhorst GJ, 2005. Long-term nitrogen supply from cattle slurry. Soil Use Manage. 21:196-204.

Schröder JJ, Uenk D, Hilhorst GJ, 2007. Long-term nitrogen fertilizer replacement value of cattle manures applied to cut grassland. Plant. Soil 299:83-99.

Sieling K, Herrmann A, Wienforth B, Taube F, Ohl S, Hartung E, Kage H, 2013. Biogas cropping systems: short term response of yield performance and $\mathrm{N}$ use efficiency to biogas residue application. Eur. J.
Agron. 47:44-54.

Sommer SG, Hutchings NJ, 2001. Ammonia emission from field applied manure and its reduction-invited paper. Eur. J. Agron. 15:1-15.

Sørensen P, 1998a. Carbon mineralization, nitrogen immobilization and $\mathrm{pH}$ change in soil after adding volatile fatty acids. Eur. J. Soil Sci. 49:457-62.

Sørensen P, 1998b. Effects of storage time and straw content of cattle slurry on the mineralization of nitrogen and carbon in soil. Bio. Fertil. Soil 27:85-91.

Sørensen P, 2004. Immobilisation, remineralisation and residual effects in subsequent crops of dairy cattle slurry nitrogen compared to mineral fertiliser nitrogen. Plant. Soil 267:285-96.

Sørensen P, Weisbjerg MR, Lund P, 2003. Dietary effects on the composition and plant utilization of nitrogen in dairy cattle manure. J. Agr. Sci. 141:79-91.

Van Kessel JS, Reeves III JB, 2002. Nitrogen mineralization potential of dairy manures and its relationship to composition. Biol. Fertil. Soils 36:118-23.

Van Kessel JS, Reeves III JB, Meisinger JJ, 2000. Nitrogen and carbon mineralization of potential manure components. J. Environ. Qual. 29:1669-77.

Webb J, Sørensen P, Velthof G, Amon B, Pinto M, Rodhe L, Salomon E, Hutchings N, Burczyk P, Reid J, 2013. An Assessment of the variation of manure nitrogen efficiency throughout Europe and an appraisal of means to increase manure-N efficiency. Adv. Agron. 119:371-442.

Zavattaro L, Monaco S, Sacco D, Grignani C, 2012. Options to reduce N loss from maize in intensive cropping systems in Northern Italy. Agr. Ecosyst. Environ. 147:24-35. 